\title{
DOES SILICON ALLEVIATE the INJURIES Of NITROGEN DEFICIENCY and FENOXAPROP-P-ETHYL HERBICIDE in WHEAT (Triticum aestivum, L.)?
}

\author{
Saudy ${ }^{1}$ H.S. and Manal Mubarak ${ }^{2}$ \\ 1- Agron. Dept., Fac. Agric., Ain Shams Univ., Shoubra El-Kheima, Cairo, Egypt \\ 2- Soil Sci. Dept., Fac. Agric., Ain Shams Univ., Shoubra El-Kheima, Cairo, Egypt
}

Keywords: Wheat; Weeds; Fenoxaprop-p-ethyl; Nitrogen deficiency; Silicon

\begin{abstract}
Si application alleviates influence of some abiotic stresses on crop plants. Meanwhile, scarce information is avaiable about the significance of $\mathrm{Si}$ for helping the plants to overcome the injuries of $\mathrm{N}$ deficiency and herbicides pressure. Thus, twoyear 2-field experiments were carried out in wheat. Experiment I involved three $\mathrm{Si}$ concentrations (Sioppm, Si 250 ppm and Si500ppm) and two $\mathrm{N}$ levels $\left(\mathrm{N}_{100 \%}\right.$ and $\left.\mathrm{N}_{50 \%}\right)$. Experiment II examined four combinations of fenoxaprop-p-ethyl and $\mathrm{Si}$ : fenoxaprop-p-ethyl+Si250ppm and fenoxaprop-pethyl+Si ${ }_{500 p m}$ (each either in sequence or in tank mixture), fenoxaprop-p-ethyl alone, hand weeding and weedy check. Under $\mathrm{N}$ deficiency $\left(\mathrm{N}_{50 \%}\right)$, Si ${ }_{500 p p m}$ increased plant height as compared to the control. No significant differences in SPAD values were detected amongst $\mathrm{Si}$ concentrations under each of the two tested $\mathrm{N}$ levels. Si can partially alleviate negative $\mathrm{N}$ deficiency effect on wheat yield, causing its increase to level obtained under normal $\mathrm{N}$ supply. Si has no effect on weed biomass when applied with fenoxaprop-p-ethyl either in sequence or in tank mixing. The most promising treatment for maximizing wheat grain yield was the application of $100 \mathrm{~kg} \mathrm{~N} \mathrm{ha}^{-1}\left(\mathrm{~N}_{50 \%}\right) \times$ fenoxapropp-ethyl+Si $250 \mathrm{ppm}$ in sequence", which also, in the same time, means reducing both cost of crop production and environment pollution.
\end{abstract}

\section{INTRODUCTION}

Nitrogen $(\mathrm{N})$ fertilization is a critical management practice required for producing maximum wheat yield. Determining the economic optimum N rate must consider both grain price and fertilizer cost. Recent increases in $\mathrm{N}$ fertilizer prices and current expectations about crop prices mean growers should consider reductions in fertilization rates in order to achieve maximum profits. With the increased cost of $\mathrm{N}$ fertilizer, dramatic swings of yield prices and concerns about the adverse environmental impacts of $\mathrm{N}$ losses, many farmersespecially in developing countries-are forced to supply the minimum limit of N. Contrarily, however, reducing $\mathrm{N}$ application rates commonly leads to lower crop yields and fewer returns. Lowering $N$ rates is expected to cause reduction in wheat growth and yield. Mattas et al (2011) mentioned that low $\mathrm{N}$ supply for wheat should have decreased net photosynthetic rate, leaf $\mathrm{N}$ percentage, plant dry weight and $\mathrm{N}$ uptake.

On the other hand, grassy weeds are one of the main constrain factor limiting wheat crop production (Wilson et al., 1990). Avena fatua and Phalaris minor are the most prevalent and harmful grassy weeds in wheat fields. They are serious competitors against wheat, where they can reduce grain yield by about 29-69 \% (Singh et al 1997; Khan et al 2007), according to infestation degree. Due to the morphological similarity between these two weeds and wheat plants in early growth stages, it is so difficult to distinguish them and can escape manual weeding. Hence, controlling both weeds through application of herbicides has been a popular option amongst farmers. Fenoxaprop-pethyl as an aryloxyphenoxypropinate herbicide, selectively controls Avena fatua (Koscelny and Peeper 1997) and Phalaris minor (Brar et al 1999) in wheat, but wheat injury from such herbicide can occur. Although the crop plants rapidly recovering from its phytotoxicity symptoms, they represent a negative impact on crop growth. Wheat susceptibility to fenoxaprop-p-ethyl (expressed as chlorosis and sometimes death) and crop injury occurred 7 to 14 days after treatment (Cataneo et al 2013). 
Visible injury in fenoxaprop-p-ethyl/safener-wheat plots was $0.4-8 \%$ and plant height was decreased as much as $6 \%$ (Soltani et al 2011).

Although the role of Silicon (Si) nutrient in plant biology and physiology has not been understood clearly, it has been shown to be beneficial for plant growth (Liang et al 1994), and the new definition of element essentiality for plant growth proposed by Epstein and Bloom (2003) emphasized that Si is an essential element for higher plants. It represents about 0.1 to $10.0 \%$ of dry weight content in different plant species (Ma et al 2006). Si deficiency causes various abnormalities in the plant ( $\mathbf{M a}$ and Takahashi, 2002) and it was commonly accepted that $\mathrm{Si}$ can positively affect growth and health status of plants under biotic (Ma, 2004) and abiotic stresses (Ranganathan et al 2006).

Despite various studies have demonstrated that Si nutrition alleviated many abiotic stresses including physical stress and chemical one like salt, metal toxicity, nutrient imbalance and many others (Epstein, 1994), the available information on its ability for mitigation the negative impact of $\mathrm{N}$ deficit and fenoxaprop-p-ethyl injury toward wheat growth and yield are scarce.

Keeping these points in mind, this study aimed to investigate the role of Si (foliar application) for alleviating the injury impact of $\mathrm{N}$ deficiency and fenoxaprop-p-ethyl herbicide on wheat growth and productivity and the efficiency against grassy weeds.

\section{MATERIALS AND METHODS}

The study was conducted at the Research and Experimental Station (30 $\left.19^{\prime} \mathrm{N}, 31^{\circ} 16^{\prime} \mathrm{E}\right)$, Faculty of Agriculture, Ain Shams University at Shalakan, Kalubia Governorate, Egypt, during the growing seasons of $2011 / 12$ and $2012 / 13$. The soil of the experimental site was clay loam, with $1.16 \%$ organic matter, $0.15 \%$ total nitrogen and $\mathrm{pH}$ 7.6. The preceding crop was sorghum in both seasons.

\section{Study procedures}

\section{Experiment I}

For detecting the possibility of $\mathrm{Si}$ in alleviating the impact of $\mathrm{N}$ deficiency potential, three Si concentrations $\left(0,250\right.$ and 500 ppm, denoted as $\mathrm{Si}_{0}$, $\mathrm{Si}_{250 p p m}$ and $\mathrm{Si}_{500 p p m}$, respectively) were tested under two $\mathrm{N}$ levels, i.e. $200 \mathrm{~kg} \mathrm{~N} \mathrm{ha}^{-1}\left(\mathrm{~N}_{100 \%}\right)$ as a recommended rate and $100 \mathrm{~kg} \mathrm{~N} \mathrm{ha}^{-1}\left(\mathrm{~N}_{50 \%}\right)$ representing an assumed $\mathrm{N}$-deficient treatment.

\section{Experiment II}

Under the same two $\mathrm{N}$ levels previously mentioned in experiment $l$, four combinations between fenoxaprop-p-ethyl herbicide $(( \pm)-2-[4-[(6-$ chloro-2-benzoxazolyl) oxy] phenoxy] propanoic acid) and $\mathrm{Si}$ (fenoxaprop-p-ethyl-Si treatments) were applied: fenoxaprop-p-ethyl+Si $250 \mathrm{ppm}$ and fenoxaprop-p-ethyl+Si500ppm (each either in sequence or in tank mixture), in addition to another three treatments which were fenoxaprop-p-ethyl alone, hand weeding 55 days after sowing (DAS) and control (weedy check).

$\mathrm{Si}$ (potassium silicate, $25 \% \mathrm{SiO}_{2}, 10 \% \mathrm{~K}_{2} \mathrm{O}$ ) was sprayed into three equal portions at 20, 40 and 60 DAS, when it applied alone (experiment I) or in sequence with the herbicide (experiment II). In experiment II, fenoxaprop-p-ethyl at a rate of $1.2 \mathrm{I} \mathrm{ha}^{-1}$ (either alone or in tank mixed with the first portion of Si) was sprayed 24 DAS, the second and third applications of Si were 40 and 60 DAS, respectively. A knapsack sprayer with one nozzle was used and the carrier was 476 I water ha-1. Nitrogen fertilizer was applied as urea $(46.5 \% \mathrm{~N})$ into two equal portions, before the first and second irrigations.

A split plot design with four replicates was used, where the main plots were occupied by $\mathrm{Si}$ concentrations (experiment $I$ ) or fenoxaprop-pethyl-Si treatments (experiment $I I$ ), while the subplots were devoted for $\mathrm{N}$ levels (in both experiments). The experimental unit area was $10.5 \mathrm{~m}^{2}$ (3.5 $\mathrm{m}$ length and $3 \mathrm{~m}$ width).

The sowing dates were 25 November in 2011 and 29 November in 2012. Wheat grains (cv. Sakha-93) were broadcasted at a rate of $143 \mathrm{~kg}$ $\mathrm{ha}^{-1}$, then followed by irrigation. In both experiments all other recommended practices in the area were adopted throughout the two seasons.

\section{Sampling and assessments}

Weed biomass: Weed growth was determined only in Experiment II. Herein, grassy weeds of one square meter from each plot were hand pulled at 80 DAS, and then weed biomass expressed in dry weight was estimated. The dry weight was recorded after air drying for 10 days and oven drying at $105^{\circ} \mathrm{C}$ for 24 hours.

Wheat: In both experiments, at 85 DAS plant height was measured and greenness (SPAD value) of flag leaf was determined by chlorophyll meter (SPAD-502) according to Soil Plant Analysis Department Section, Minolta Camera Co., Osaka, 
Japan as reported by Minolta (1989). Also, Flag leaves of 10 plants were isolated to measure flag leaf $\mathrm{N} \%$ using micro-Kjeldahl apparatus according to AOAC (1995). At harvest (on 10 and 15 May in $2011 / 12$ and 2012/13, respectively), plants of square meter per each plot were collected to estimate spike weight $\mathrm{m}^{-2}$ and grain yield $\mathrm{ha}^{-1}$. Afterward, ten main shoots were taken from each plot to measure grain weight spike ${ }^{-1}$ and weight of $1000-$ grain. For detecting grain protein \%, samples of $100 \mathrm{~g}$ of grains were grinned into fine powder and dried at $70^{\circ} \mathrm{C}$. Then, grain $\mathrm{N} \%$ was determined using micro-Kjeldahl apparatus according to AOAC (1995). Moreover, grain crude protein \% was calculated by multiplying grain $\mathrm{N} \%$ by 5.7 .

\section{Data analysis}

All the obtained data from each season were exposed to the proper statistical analysis of variance according to Gomez and Gomez (1984). The combined analysis of variance for the data of the two seasons was performed after testing the error homogeneity. LSD at 0.05 level of significance was used for the comparison between means of treatments.

\section{RESULTS AND DISCUSSION}

\section{Experiment I}

\section{Plant height and SPAD value}

Increasing $N$ level caused increases in plant height and SPAD value of wheat, where $\mathrm{N}_{100 \%}$ surpassed $\mathrm{N}_{50 \%}$ (Figure 1). The enhancement of wheat plant height and SPAD value with increasing $N$ rate might be due to the vital role of $\mathrm{N}$ in cell division and elongation in addition to it is a component in chlorophyll structural formation. Singh et al (2002) reported that SPAD readings positively related to chlorophyll levels in wheat plant tissue which highly correlated with leaf $\mathrm{N}$ content. The beneficial effect of $\mathrm{N}$ on wheat plant height and SPAD value was reported by Saudy et al (2008).

Data analysis showed that application of Si500ppm achieved the tallest wheat plants with significant increases reached 4.4 and $2.7 \%$, compared to $\mathrm{Si}_{0 \mathrm{ppm}}$ and $\mathrm{Si}_{250 \mathrm{ppm}}$, respectively (Figure 2). Such result could be attributed to that $\mathrm{Si}$ in- creased cell growth and nutrient uptake by crop plants. Si has a vital role in enhancement cell elongation as a result of Si-enhanced extensibility of the cell in rice (Hossain et al 2002) and promotion of $\mathrm{K}$ uptake (Liang et al 1999). Gong et al (2003) observed that Si increased plant height, leaf area and dry mass of wheat. On the other hand, Si application has no significant effect on SPAD value (Figure 2). Fallah (2012) reported that the chlorophyll meter reading was not affected by Si treatment.

The interaction between $\mathrm{N}$ level and Si concentration in affecting plant height and SPAD value was significant (Figure 3). Si 500ppm $_{5}$ along with $\mathrm{Si}_{250 p p m}$ under $\mathrm{N}_{100 \%}$ were the effective combinations for enhancing plant height. Moreover, under $\mathrm{N}$ deficiency $\left(\mathrm{N}_{50 \%}\right)$, application of $\mathrm{Si}_{500 \mathrm{ppm}}$ increased plant height than the control. Si has been reported to enhance growth of several higher plants particularly under abiotic stresses (Epstein, 1999). However, various studies have demonstrated that Si application significantly increased plant growth under normal conditions (Agurie et al 1992) and abiotic stress ones (Ranganathan et al 2006). These beneficial effects are mostly expressed through Si deposition in the leaves, stems, and hulls (Ma, 2004). In the second order, no significant differences in SPAD values were detected amongst Si concentrations under each of the two tested $\mathrm{N}$ levels (Figure 3 ). Such result shows that $\mathrm{Si}$ has no marked role in chlorophyll formation either under normal or lower $\mathrm{N}$ supplies.

\section{Yield and its attributes}

As shown in Table (1), $N_{100 \%}$ significantly increased the spike weight $\mathrm{m}^{-2}$ and grain yield ha ${ }^{-1}$ by 22.0 and $14.4 \%$, respectively and decreased 1000 -grain weight by $6.9 \%$ compared with $\mathrm{N}_{50 \%}$. Grain weight spike $^{-1}$, however, was not affected. The improved wheat yield with increasing $N$ rate might be attributed to the effective role of $\mathrm{N}$, as an essential constituent of chlorophylls which represent the machinery of photosynthesis process, on dry matter accumulation. Additionally, $\mathrm{N}$ fertilizer influences the production of carbohydrates by affecting the mean leaf area available to intercept solar radiation and to absorb $\mathrm{CO}_{2}$. The improvements in wheat yield and its components with increasing $\mathrm{N}$ rates were also obtained by Sobh et al (2000) and Saudy et al (2008). 

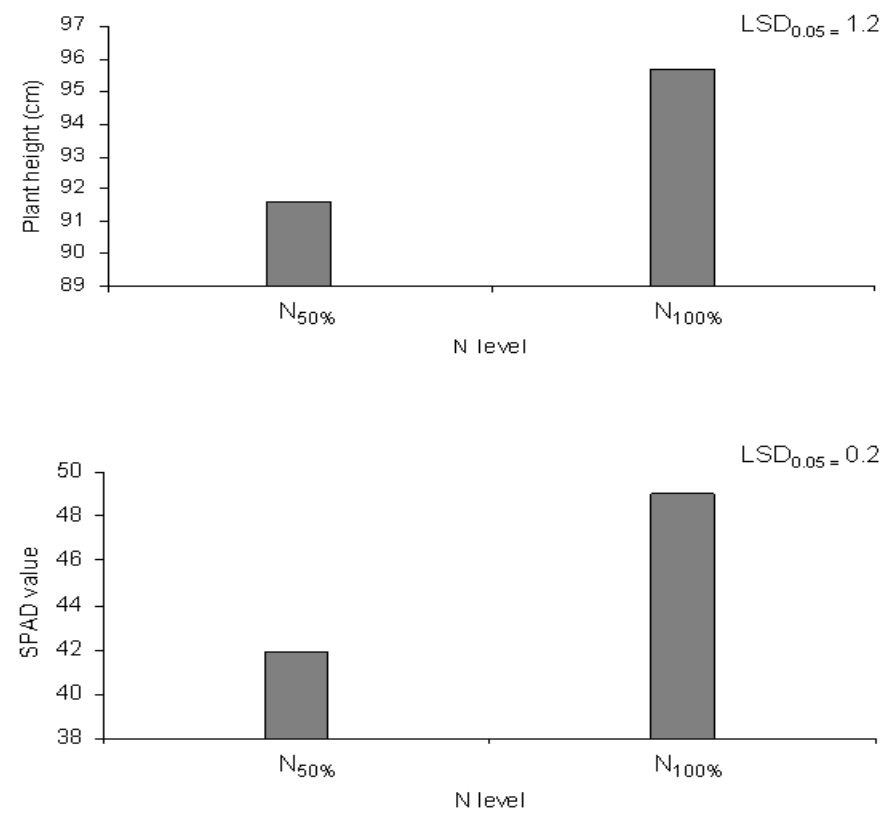

Figure 1. Wheat plant height and SPAD value as influenced by the applied $\mathrm{N}$ level $(50 \%$ and $100 \%$ of the recommended rate)
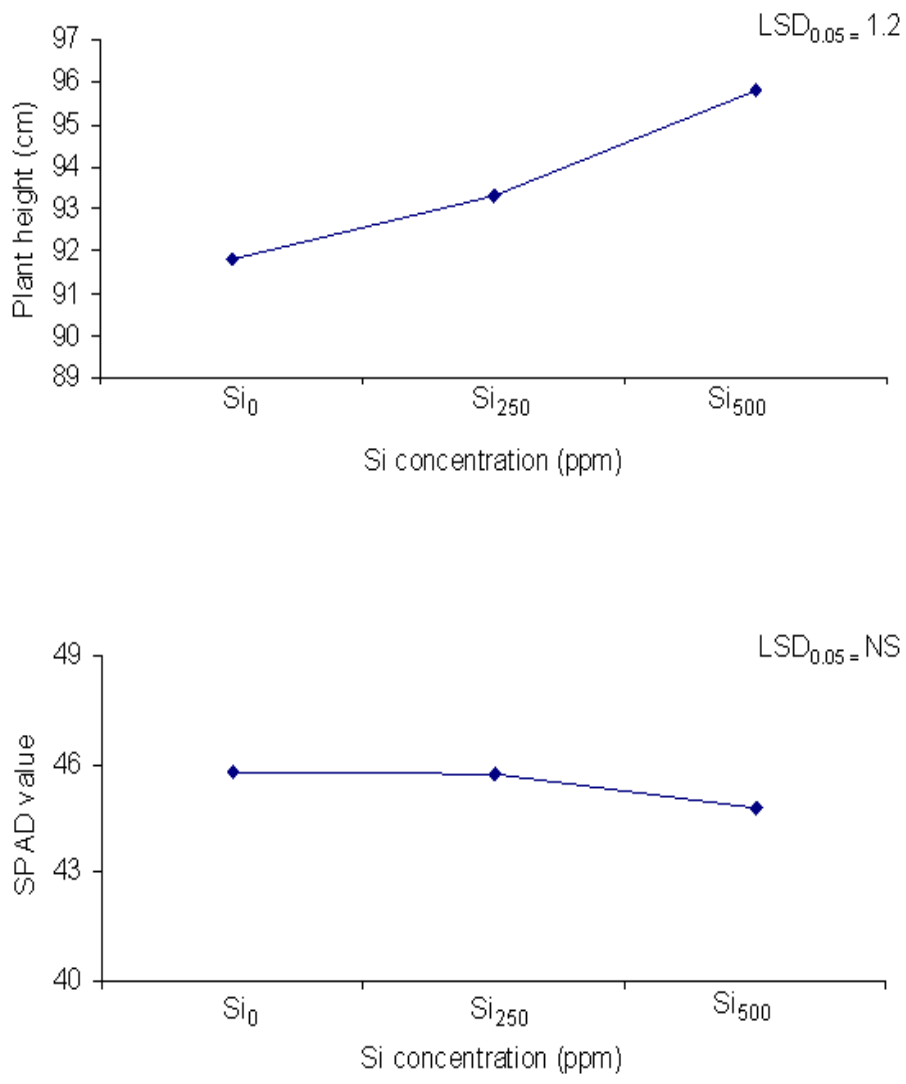

Figure 2. Wheat plant height and SPAD value as influenced by the applied Si concentration (NS: Not significant) 

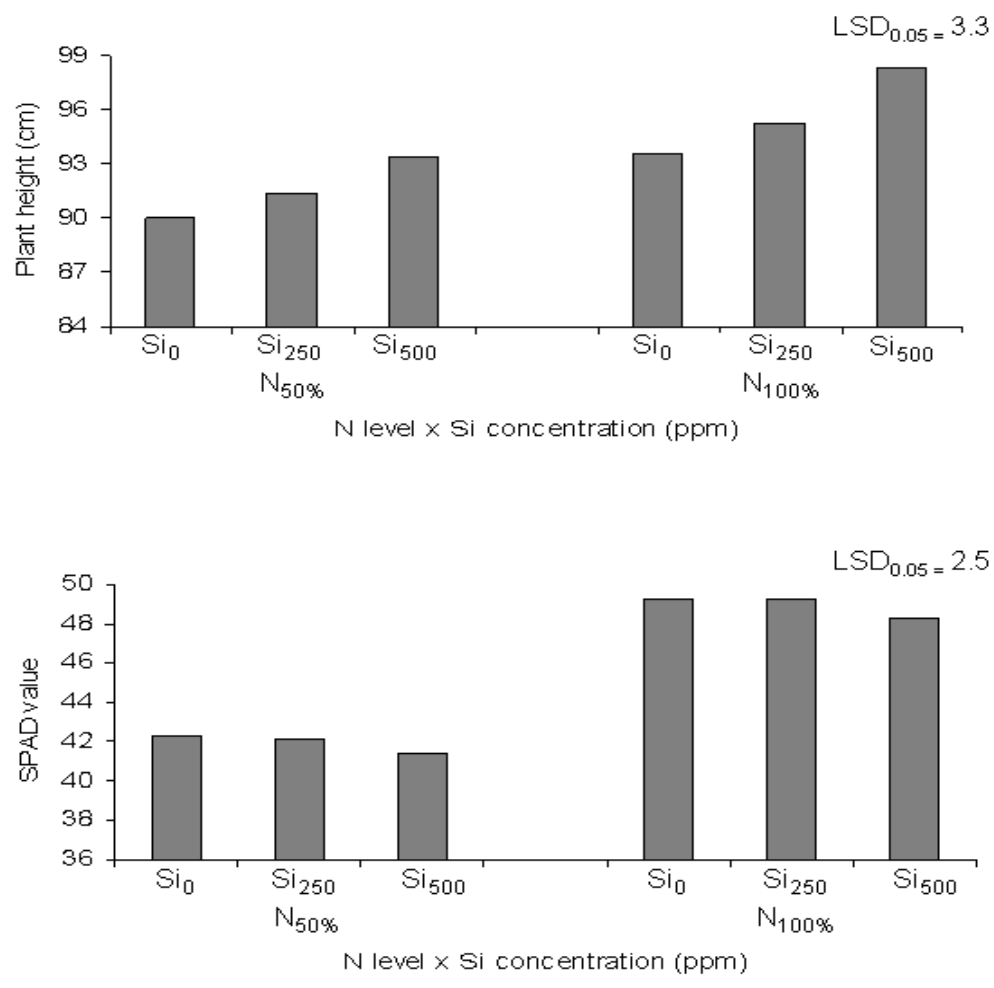

Figure 3. Wheat plant height and SPAD value as influenced by the interaction between $\mathrm{N}$ level and $\mathrm{Si}$ concentration

Application of Si500ppm increased spike weight $\mathrm{m}^{-2}$ and grain yield $\mathrm{ha}^{-1}$ by about 15.2 and $15.8 \%$, respectively compared with Sioppm (Table 1). Such findings could be attributed to the indirect effect of Si for promoting dry matter accumulation by enhancing nutrients uptake. In this respect, Tahir et al (2006) indicated that Si enhanced K/Na selectivity ratio in wheat genotypes enhancing dry matter and grain yield. Thus the increased $\mathrm{K}$ uptake and decreased $\mathrm{Na}$ uptake by addition of $\mathrm{Si}$ was the major mechanisms responsible for better growth, reflecting on yield. Also, Ma and Takahashi (1990) concluded that there is a high $\mathrm{P}$ uptake in rice with Si application which directly correlates the increased growth and yield.

The maximum value in spike weight $\mathrm{m}^{-2}(686.4$ g) was produced by $\mathrm{N}_{100 \%} \times \mathrm{Si}_{500 \mathrm{ppm}}$, but statistically equaled with $\mathrm{N}_{100 \%} \times \mathrm{Si}_{250 \mathrm{ppm}}$ or $\mathrm{N}_{100 \%} \times \mathrm{Si}_{0 p p m}$ (Table 1). Si improves light interception by keeping leaves erect, thereby stimulating canopy photosynthesis in rice (Ma and Takahashi, 2002). This is particularly important in dense plant stands and when nitrogen fertilizers are heavily applied so as to minimize mutual shading. The maximum value of 1000 -grain weight was recorded by $N_{50 \%} x$ Sioppm. In addition, application of each Si concen- tration under $\mathrm{N}_{50 \%}$ exceeded its corresponding under $\mathrm{N}_{100 \%}$. With the exception of $\mathrm{N}_{50 \%} \times$ Sioppm, all other interactions between $\mathrm{N}$ levels and $\mathrm{Si}$ concentrations were statistically at par in grain yield. Reductions in wheat grain yield due to reducing $\mathrm{N}$ level from $\mathrm{N}_{100 \%}$ to $\mathrm{N}_{50 \%}$ in plots treated with Sioppm, $\mathrm{Si}_{250 \mathrm{ppm}}$ or $\mathrm{Si}_{500 \mathrm{ppm}}$ amounted to $28.8,1.8$ and $8.4 \%$, respectively. Such finding emphasizes that $\mathrm{Si}$ can partially compensate $\mathrm{N}$ deficiency, mitigating the reduction in wheat yield by $20.4-27 \%$.

\section{Flag leaf $\mathbf{N}$ and grain protein $\%$}

There were significant effects of $\mathrm{N}$ level on flag leaf $\mathrm{N}$ and grain protein \% of wheat (Figure $4 \mathrm{a}$ ). $\mathrm{N}_{100 \%}$ increased such two traits by 18.4 and $16.9 \%$, respectively over those of $\mathrm{N}_{50 \%}$. This finding could be due to the significance of nitrogen as a major structural element for chlorophyll and protein synthesis. Moreover, increment in flag leaf $\mathrm{N} \%$ was obtained with the increase in $\mathrm{Si}$ concentration, where the maximum value was recorded with Si ${ }_{500 p p m}$ (Figure $4 \mathbf{b}$ ). Otherwise, grain protein \% progressively decreased with increase in Si concentration. Such result is agreed with observation of Morimiya (1996), who reported that sufficient 
Table 1. Wheat yield and its attributes as influenced by the applied $\mathrm{N}$ level, Si concentration and their interaction

\begin{tabular}{|c|c|c|c|c|c|}
\hline \multicolumn{2}{|c|}{ Treatments } & $\begin{array}{c}\text { Spike } \\
\text { weight } \\
\left(\mathrm{g} \mathrm{m}^{-2}\right)\end{array}$ & $\begin{array}{l}\text { Grain weight } \\
\text { spike }^{-1}(\mathrm{~g})\end{array}$ & $\begin{array}{l}\text { 1000-grain } \\
\text { weight }(g)\end{array}$ & $\begin{array}{l}\text { Grain yield } \\
\qquad\left(\mathrm{t} \mathrm{ha}^{-1}\right)\end{array}$ \\
\hline \multicolumn{6}{|l|}{ N level } \\
\hline \multicolumn{2}{|l|}{$\mathrm{N}_{50 \%}$} & 525.2 & 2.25 & 47.7 & 4.52 \\
\hline \multicolumn{2}{|l|}{$\mathrm{N}_{100 \%}$} & 640.7 & 2.30 & 44.4 & 5.17 \\
\hline \multicolumn{2}{|l|}{$\mathrm{LSD}_{0.05}$} & 59.2 & NS & 1.5 & 0.41 \\
\hline \multicolumn{6}{|c|}{ Si concentration (ppm) } \\
\hline \multicolumn{2}{|l|}{ Sioppm } & 538.6 & 2.19 & 46.1 & 4.49 \\
\hline \multicolumn{2}{|l|}{$\mathrm{Si}_{250 \mathrm{ppm}}$} & 589.7 & 2.25 & 45.7 & 4.85 \\
\hline \multicolumn{2}{|l|}{ Si $500 p p m$} & 620.6 & 2.39 & 46.3 & 5.20 \\
\hline \multicolumn{2}{|l|}{$\mathrm{LSD}_{0.05}$} & 55.5 & NS & NS & 0.49 \\
\hline \multicolumn{6}{|l|}{$N \times S i$} \\
\hline \multirow[t]{3}{*}{$\mathrm{N}_{50} \%$} & Sioppm & 439.9 & 2.26 & 48.7 & 3.79 \\
\hline & $\mathrm{Si}_{250 \mathrm{ppm}}$ & 580.9 & 2.11 & 46.9 & 4.80 \\
\hline & Si $i_{500 p p m}$ & 554.7 & 2.39 & 47.5 & 4.97 \\
\hline \multirow[t]{3}{*}{$\mathrm{N}_{100 \%}$} & Sioppm & 637.2 & 2.12 & 43.5 & 5.20 \\
\hline & $\mathrm{Si}_{250 \mathrm{ppm}}$ & 598.5 & 2.39 & 44.5 & 4.89 \\
\hline & $\mathrm{Si}_{500 \mathrm{ppm}}$ & 686.4 & 2.38 & 45.2 & 5.42 \\
\hline \multicolumn{2}{|l|}{$\mathrm{LSD}_{0.05}$} & 90.9 & NS & 2.2 & 0.81 \\
\hline
\end{tabular}

NS: Not significant
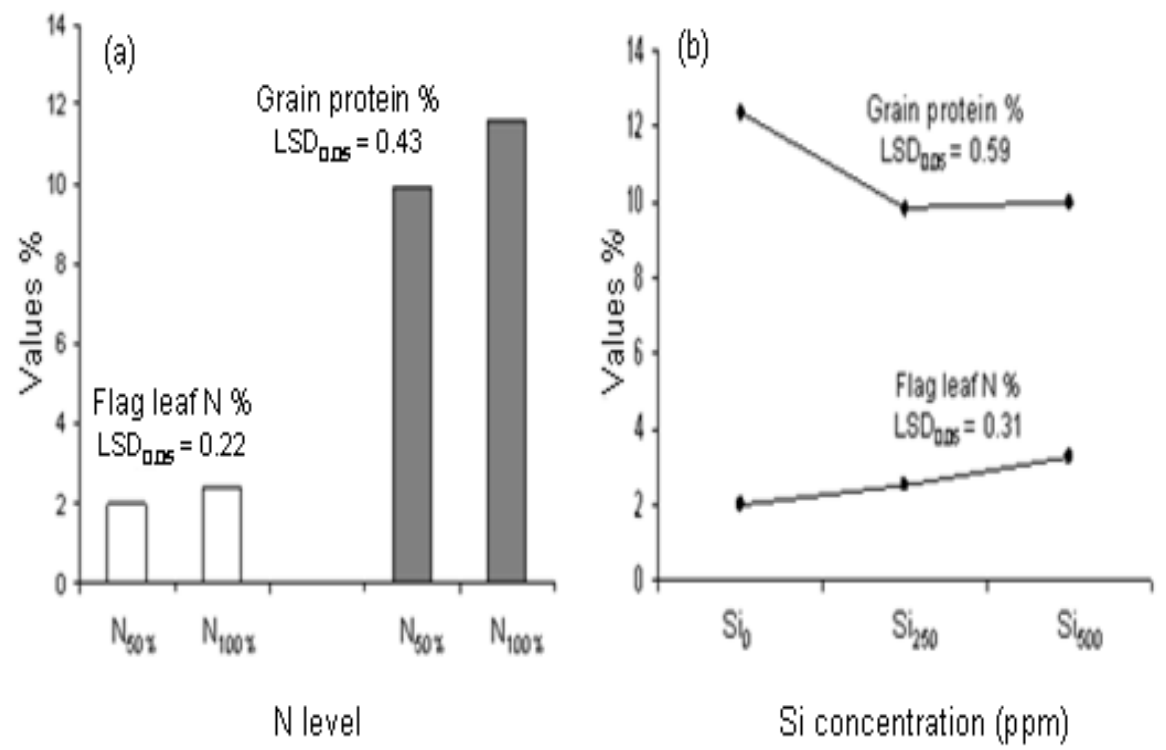

Figure 4. Flag leaf $\mathrm{N}$ and grain protein \% of wheat as influenced by the applied (a) N level and (b) Si concentration 
supply of Si to rice gave low protein. Also, Ahmad and Haddad (2011) found that Si treatment decrease total soluble protein content than that in non-Si treatment.

All possible interactions between $\mathrm{N}$ level and $\mathrm{Si}$ concentration were statistically equaled in flag leaf $\mathrm{N}$, except $\mathrm{N}_{50 \%} \times \mathrm{Si}_{0 p p m}$ which showed the lowest value (Figure 5). Also, with no Si application, $\mathrm{N}_{100 \%}$ produced higher grain protein $\%$.

\section{Experiment II}

During both growing seasons, the dominant weeds were annual grasses, i.e. wild oat (Avena fatua) and canary grass (Phalaris minor). These two weed species represented about 72 and $28 \%$, respectively, of the total weeds presented in the weedy check plots.

\section{Weed biomass}

Data in Table (2) showed that weed biomass responded markedly and negatively to $\mathrm{N}$ application. Grassy weeds produced higher dry weight in plots fertilized with $\mathrm{N}_{50 \%}$ compared to $\mathrm{N}_{100 \%}$. This may be attributed to the enhancement in vegetative growth of wheat plants with higher $\mathrm{N}$ rate, leading to increasing their competitiveness against weeds grown beneath them. Increasing $\mathrm{N}$ rates applied to winter wheat decreased annual grass weed populations (Valenti and Wicks, 1992) and total weed biomass (Jornsgard et al 1996).

All treatments of fenoxaprop-p-ethyl plus Si as well as hand weeding significantly decreased weed biomass than the control (Table 2). In this connection, fenoxaprop-p-ethyl+Si 250 ppm in tank mixture achieved the maximal reduction in weed biomass, with no statistical differences with other weeded treatments. Such result refers to that Si has no synergistic or antagonistic herbicidal effect when applied with fenoxaprop-p-ethyl either in sequence or in tank mixing. Thus, it is emphasizing that the efficiency in weed elimination is assumed to be completely attributed to the herbicide. Therein, fenoxaprop-p-ethyl is a post-emergence herbicide that inhibits Acetyl Coenzyme A Carboxylase (ACCase), the enzyme needed for fatty acid synthesis and subsequent production of phospholipids needed for cell membranes in plants. The herbicide is very effective for the control of a wide spectrum of annual grass in wheat (Senseman, 2007). El-Metwally and Saudy (2009) noticed high efficiency of fenoxaprop-p-ethyl for eliminating grassy weeds in wheat reached $97.7 \%$.
On the other hand, the interaction between $\mathrm{N}$ levels and weeded treatments in affecting weed biomass was significant (Table 2). Although each fenoxaprop-p-ethyl-Si treatment under $\mathrm{N}_{50 \%}$ tend to lowering weed biomass than its counterpart under $\mathrm{N}_{100 \%}$, the significance was recorded only with fenoxaprop-p-ethyl+Si ${ }_{500 p m}$ in sequence which caused significant reduction with $\mathrm{N}_{100 \%}$ than $\mathrm{N}_{50 \%}$.

\section{Wheat}

It is striking to mention that the effect of $\mathrm{N}$ levels on plant height and SPAD value (Table 3 ) spike weight $\mathrm{m}^{-2}$, grain weight spike ${ }^{-1}, 1000$-grain weight and grain yield ha-1 (Table 4) as well as flag leaf $\mathrm{N}$ and grain protein \% of wheat (Table 5) in the experiment $/ /$ had similar trends recorded for the same traits in the experiment I (Figure 1, Table 1 and Figure 4). So, it suggested that there is no need to repeat the explanation and discussion in this regard.

\section{Plant height and SPAD}

Fenoxaprop-p-ethyl had an adverse effect on wheat plant height and SPAD value, causing 5.4 and $6.0-6.8 \%$ reductions compared to control and hand weeding, respectively (Table 3). Soltani et al (2011) found that fenoxaprop-p-pethyl/safener decreased wheat plant height by $6 \%$. On the other hand, fenoxaprop-p-ethyl+Si $250 p p m$ or fenoxaprop$\mathrm{p}$-ethyl+Si ${ }_{500 p m}$ either in sequence or in tank mixture application enhanced plant height by $6.3,6.0$, 7.2 and $6.8 \%$, respectively, than fenoxaprop-pethyl alone (Table 3). Also, sequence application of fenoxaprop-p-ethyl+Si 250 ppm or fenoxaprop-pethyl+Si $i_{500 p m}$ increased SPAD value by 4.5 and $8.6 \%$, respectively, than fenoxaprop-p-ethyl alone. Such results show the potentiality of using Si as a protective element for overcoming the injury impact of fenoxaprop-p-ethyl toward wheat plants, beside its beneficial effect on plant growth. Si alleviated effects have been associated with an increase in antioxidant defense abilities and enhanced plant tolerance to abiotic stresses (Liang et al 2003; 2005 and Gong et al 2005). Poaceae family species accumulate large amounts of $\mathrm{Si}$ and Si application to these crops ensured better growth (Mitani and Ma, 2005).

Data of the interaction between $\mathrm{N}$ levels and fenoxaprop-p-ethyl-Si treatments revealed generally that the injury impact of fenoxaprop-p-ethyl toward wheat plants is plainly evident under $\mathrm{N}$ stress (Table 3). Therefore, the reductions in plant 

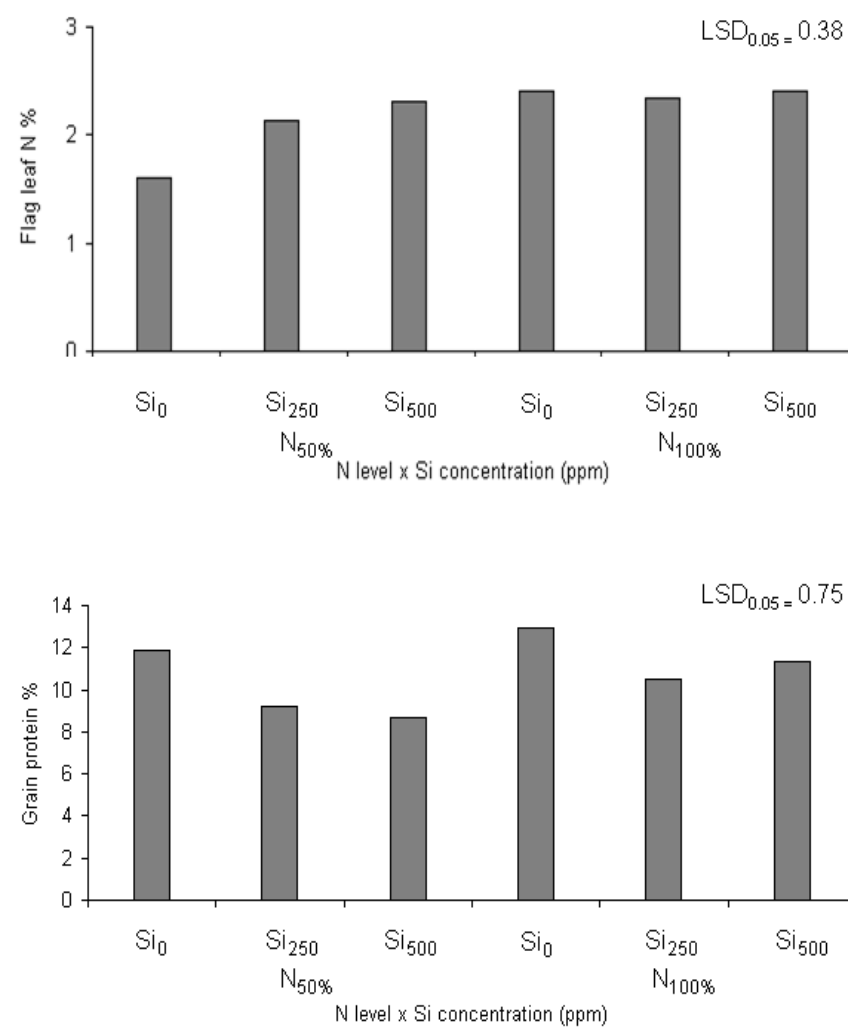

Figure 5. Flag leaf $\mathrm{N}$ and grain protein \% of wheat as influenced by the interaction between the applied $\mathrm{N}$ level and Si concentration

Table 2. Weed biomass $\left(\mathrm{g} \mathrm{m}^{-2}\right)$ as influenced by the applied $\mathrm{N}$ level $(\mathrm{N})$, fenoxaprop-p-ethyl-Si treatment $(F)$ and their interaction in wheat

\begin{tabular}{|c|c|c|c|c|}
\hline \multirow[t]{2}{*}{ Treatments } & & \multicolumn{2}{|c|}{$\mathrm{N}$ level } & \multirow{2}{*}{ Mean } \\
\hline & & $\mathrm{N}_{50 \%}$ & $\mathrm{~N}_{100 \%}$ & \\
\hline \multicolumn{5}{|l|}{ Fenoxaprop-p-ethyl-Si } \\
\hline Control & & 712.7 & 410.1 & 561.4 \\
\hline Hand weeding & & 180.5 & 80.2 & 130.4 \\
\hline Fenoxaprop-p-ethyl & & 240.3 & 141.4 & 190.9 \\
\hline Fenoxaprop-p-ethyl +Si 250ppm " & & 180.9 & 133.1 & 157.0 \\
\hline 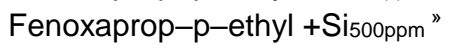 & & 187.3 & 49.3 & 118.3 \\
\hline Fenoxaprop-p-ethyl +Si $250 \mathrm{ppm}^{\&}$ & & 150.7 & 46.0 & 98.4 \\
\hline Fenoxaprop-p-ethyl $+\mathrm{Si}_{500 \mathrm{ppm}^{\&}}$ & & 183.2 & 114.4 & 148.8 \\
\hline Mean & & 262.2 & 139.2 & \\
\hline \multirow[t]{3}{*}{$\mathrm{LSD}_{0.05}$} & $\mathrm{~N}$ & 17.0 & & \\
\hline & $\mathrm{F}$ & 172.0 & & \\
\hline & $\mathrm{N} \times \mathrm{F}$ & 127.9 & & \\
\hline
\end{tabular}

»: Sequence application of fenoxaprop-p-ethyl plus $\mathrm{Si}$, \&: Tank mixing application of fenoxaprop-pethyl plus $\mathrm{Si}$ 
Table 3. Wheat plant height and SPAD value as influenced by the applied $\mathrm{N}$ level $(\mathrm{N})$, fenoxaprop-p-ethyl-Si treatment $(F)$ and their interaction

\begin{tabular}{|c|c|c|c|c|c|c|c|}
\hline \multirow{2}{*}{\multicolumn{2}{|c|}{ Treatment }} & \multicolumn{2}{|c|}{ Plant height (cm) } & \multirow{2}{*}{ Mean } & \multicolumn{2}{|c|}{ SPAD value } & \multirow{2}{*}{ Mean } \\
\hline & & $\mathbf{N}_{50 \%}$ & $\mathbf{N}_{100 \%}$ & & $\mathbf{N}_{50} \%$ & $\mathbf{N}_{100 \%}$ & \\
\hline \multicolumn{2}{|l|}{ Control } & 91.0 & 94.5 & 92.8 & 45.3 & 49.2 & 47.3 \\
\hline \multicolumn{2}{|c|}{ Hand weeding } & 90.0 & 95.5 & 92.8 & 44.7 & 49.1 & 46.9 \\
\hline \multicolumn{2}{|c|}{ Fenoxaprop-p-ethyl } & 82.5 & 93.0 & 87.8 & 40.6 & 47.5 & 44.1 \\
\hline \multicolumn{2}{|c|}{ Fenoxaprop-p-ethyl +Si250ppm" } & 91.0 & 95.5 & 93.3 & 43.4 & 48.8 & 46.1 \\
\hline \multicolumn{2}{|c|}{ Fenoxaprop-p-ethyl +Si i00ppm } & 91.4 & 94.8 & 93.1 & 46.5 & 49.2 & 47.9 \\
\hline \multicolumn{2}{|c|}{ Fenoxaprop-p-ethyl $+\mathrm{Si}_{250 \mathrm{ppm}^{\&}}$} & 92.9 & 95.3 & 94.1 & 41.4 & 48.6 & 45.0 \\
\hline \multicolumn{2}{|c|}{ Fenoxaprop-p-ethyl +Si500ppm ${ }^{\&}$} & 91.8 & 95.8 & 93.8 & 41.5 & 49.9 & 45.7 \\
\hline \multicolumn{2}{|l|}{ Mean } & 90.1 & 94.9 & & 43.3 & 48.9 & \\
\hline \multirow[t]{3}{*}{ LSD $_{0.05}$} & $\mathrm{~N}$ & 1.6 & & & 1.3 & & \\
\hline & $\mathrm{F}$ & 2.8 & & & 1.8 & & \\
\hline & $\mathrm{N} \times \mathrm{F}$ & 3.7 & & & 1.6 & & \\
\hline
\end{tabular}

height and SPAD value due to fenoxaprop-p-ethyl were more noticeable with $\mathrm{N}_{50 \%}$ than $\mathrm{N}_{100 \%}$. As an average of fenoxaprop-p-ethyl-Si treatments, plant height was increased by $11.2 \%$ than fenoxaprop-p-ethyl alone in plots received $\mathrm{N}_{50 \%}$. In plots fertilized with $\mathrm{N}_{100 \%}$, fenoxaprop-p-ethyl+Si $i_{500 p p m}$ in tank mixture showed the maximum plant height $(95.8 \mathrm{~cm})$. Under $\mathrm{N}_{50 \%}$, fenoxaprop-p-ethyl + $\mathrm{Si}_{500 p p m}$ in sequence was the effective interaction for producing the highest SPAD value (46.5).

\section{Yield and its attributes}

Spike weight $\mathrm{m}^{-2}$, grain weight spike ${ }^{-1}, 1000$ grain weight and grain yield ha ${ }^{-1}$ of wheat were statistically responded to fenoxaprop-p-ethyl-Si treatments (Table 4). Maximum values were recorded with hand weeding (for spike weight $\mathrm{m}^{-2}$ ) and with the single application of fenoxaprop-pethyl or with sequence application of fenoxaprop-

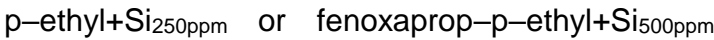
(for grain weight spike ${ }^{-1}$ and 1000 -grain weight). Moreover, the distinctive treatment for enhancing grain yield was fenoxaprop-p-ethyl+Si $250 \mathrm{ppm}$ in sequence surpassing other fenoxaprop-p-ethylSi treatments. Such potent treatment caused 30.5 and $6.7 \%$ increases in grain yield compared with fenoxaprop-p-ethyl alone and hand weeding, respectively. Fenoxaprop-p-ethyl+Si $i_{500 p m}$ in sequence along with hand weeding and fenoxapropp-ethyl+Si 250 ppm in sequence came in the descending order in this respect, causing 22.4, 22.4 and $16.1 \%$ increases in grain yield, respectively, compared with fenoxaprop-p-ethyl alone. The improvements in wheat yield and its components due to the marked fenoxaprop-p-ethyl-Si treatments could be attributed to the high efficiency of fenoxaprop-p-ethyl herbicide for controlling grassy weeds (Table 2), and complementary effect of fenoxaprop-p-ethyl plus Si for enhancing plant growth (Table 3 ), reflecting on grain weight spike ${ }^{-1}$ and 1000-grain weight, then on grain yield. Si application has a positive effect on crop net assimilation rate (Ahmed et al 2012) with improving crop dry mass and yield (Rodrigues et al 2004). Mukkram et al (2006) also found that $\mathrm{Si}$ increased wheat growth and yield due to decreased $\mathrm{Na}^{+}$uptake. Wheat grain yield was increased by $16.2 \%$ with application of fenoxaprop-p-ethyl (EIMetwally and Saudy, 2009).

In the second order, the highest values for grain weight spike ${ }^{-1}$ and 1000 -grain weight were gained with fenoxaprop-p-ethyl used alone and fenoxaprop-p-ethyl+Si $250 \mathrm{ppm}$ in sequence each under $\mathrm{N}_{50 \%}$ ( $\mathrm{N}$ deficiency conditions), respectively. Spike weight $\mathrm{m}^{-2}$ and grain yield were gained with hand weeding under $\mathrm{N}_{100 \%}$ (normal $\mathrm{N}$ conditions), see Table (4). Furthermore, when applied $\mathrm{N}$ was reduced at $\mathrm{N}_{50 \%}$ (half of the recommended rate), the decreases were recorded in spike weight $\mathrm{m}^{-2}$ (with application of hand weeding, fenoxaprop-pethyl+Si500ppm in sequence, or fenoxaprop-pethyl+Si $250 \mathrm{ppm}$ in tank mixture), and in grain weight spike $^{-1}$ (with application of fenoxaprop-pethyl+Si $\mathrm{S}_{250 \mathrm{ppm}}$ in sequence). But, the increases, however, were detected in 1000-grain weight with application of all fenoxaprop-p-ethyl-Si treatments except with fenoxaprop-p-ethyl used alone. Also, it is noted that each treatment of fenoxaprop$\mathrm{p}$-ethyl-Si under $\mathrm{N}_{50} \%$ produced grain yield statistically equal with the corresponding one under 
Table 4. Wheat yield and its attributes as influenced by the applied $\mathrm{N}$ level, fenoxaprop-p-ethyl-Si treatment and their interaction

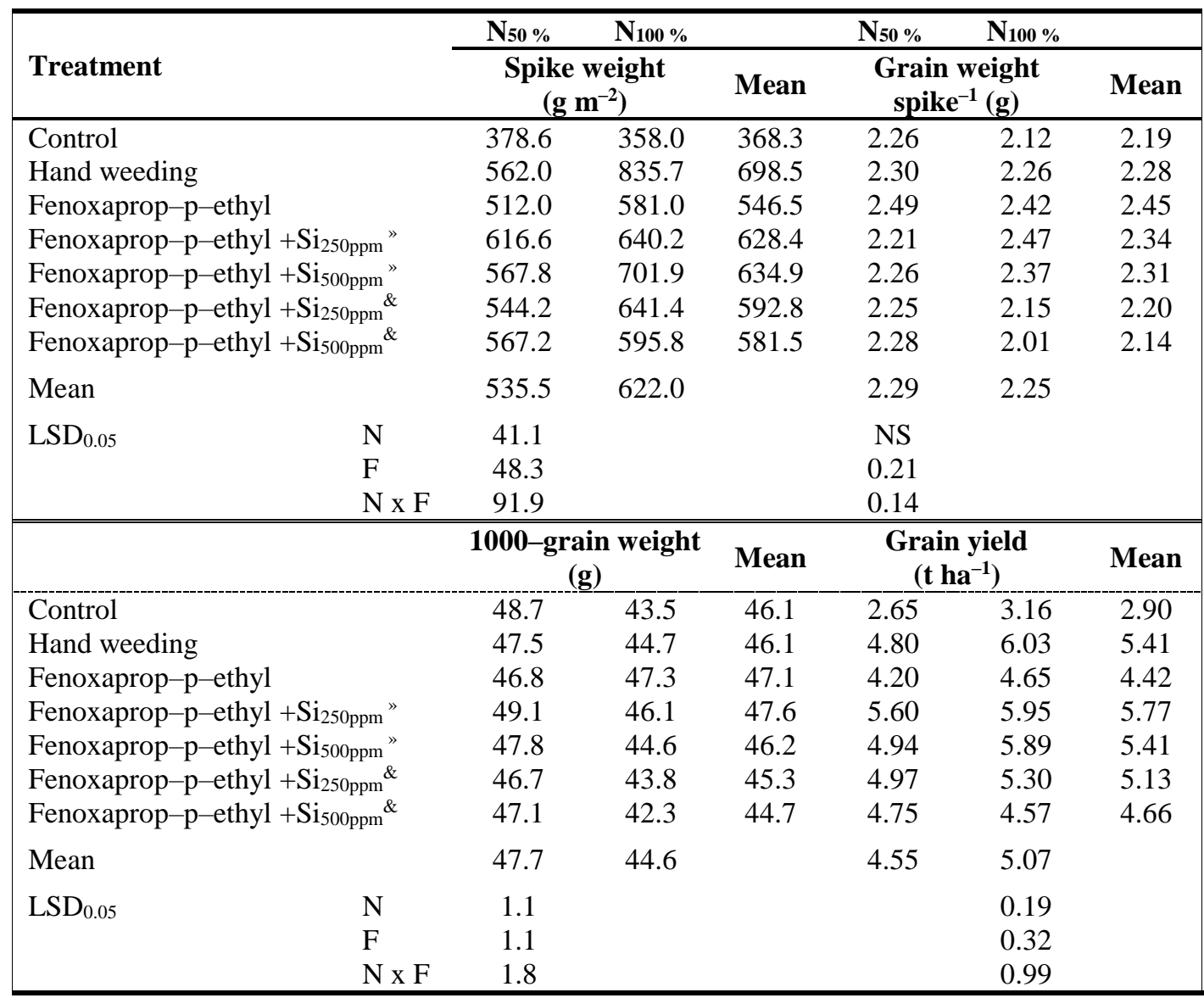

»: Sequence application of fenoxaprop-p-ethyl plus $\mathrm{Si}$, \&: Tank mixing application of fenoxaprop-p-ethyl plus $\mathrm{Si}$,

NS: Not significant

$\mathrm{N}_{100 \%}$, except that of hand weeding which produced higher yield under $\mathrm{N}_{100 \%}$. The latter treatment combination was the superior in wheat yield productivity but without significant differences with those produced by fenoxaprop-p-ethyl+Si $\mathrm{S}_{250 \mathrm{ppm}}$ in sequence under $\mathrm{N}_{50 \%}$, fenoxaprop-p-ethyl + $\mathrm{Si}_{250 p m}$ in sequence, fenoxaprop-p-ethyl+Si ${ }_{500 p m}$ in tank mixture, or fenoxaprop-p-ethyl+Si $250 \mathrm{ppm}$ in tank mixture each under $\mathrm{N}_{100 \%}$ (Table 4). Grain yield of wheat genotypes under stressed conditions and Si application found to be positively correlated with photosynthesis, stomatal conductance and chlorophyll contents (Ahmed et al 2012). Herein, and as our data indicated, the most promising (and could be recommended) treatment for maximizing wheat grain yield was the application of "100 kg N ha-1, $\mathrm{N}_{50} \%$ " x "fenoxaprop-p-ethyl + $\mathrm{Si}_{250 \mathrm{ppm}}$ in sequence", which also, in the same time, means reducing both crop production cost and environment pollution.

\section{Flag leaf $\mathbf{N}$ and grain protein $\%$}

Fenoxaprop-p-ethyl caused reductions in flag leaf $\mathrm{N} \%$ reached 6.0 and $13.7 \%$ compared to the control and hand weeding, respectively. While, addition of Si plus fenoxaprop-p-ethyl modified this effect, where flag leaf $\mathrm{N} \%$ was enhanced by $28.2,23.9$ or $23.4 \%$ with mixing of fenoxaprop-pethyl+Si500ppm and sequencing of fenoxaprop-pethyl+Si ${ }_{500 p p m}$ or fenoxaprop-p-ethyl+Si $250 \mathrm{ppm}$, respectively, compared to fenoxaprop-p-ethyl alone (Table 5). Contrariwise, addition of Si plus fenoxaprop-p-ethyl either in tank mixture or in sequence lowered grain protein \% than the control or 
fenoxaprop-p-ethyl alone. Under $\mathrm{N}_{100 \%}$, the maxi- mum

Table 5. Flag leaf $\mathrm{N}$ and grain protein content (\%) of wheat as influenced by the applied $\mathrm{N}$ level $(\mathrm{N})$, fenoxaprop-p-ethyl-Si treatment $(\mathrm{F})$ and their interaction

\begin{tabular}{|c|c|c|c|c|c|c|}
\hline \multirow{2}{*}{ Treatment } & \multicolumn{2}{|c|}{ Flag leaf $\mathrm{N} \%$} & \multirow{2}{*}{ Mean } & \multicolumn{2}{|c|}{ Grain protein \% } & \multirow{2}{*}{ Mean } \\
\hline & $\mathrm{N}_{50 \%}$ & $\mathbf{N}_{100 \%}$ & & $\mathbf{N}_{50} \%$ & $\mathbf{N}_{100 \%}$ & \\
\hline Control & 1.60 & 2.40 & 2.00 & 11.62 & 11.14 & 11.38 \\
\hline Hand weeding & 2.00 & 2.37 & 2.18 & 10.00 & 11.70 & 10.85 \\
\hline Fenoxaprop-p-ethyl & 1.84 & 1.92 & 1.88 & 9.77 & 11.66 & 10.71 \\
\hline Fenoxaprop-p-ethyl +Si $250 \mathrm{ppm} "$ & 2.13 & 2.51 & 2.32 & 9.14 & 10.62 & 9.88 \\
\hline Fenoxaprop-p-ethyl +Si i500pm " & 2.23 & 2.43 & 2.33 & 9.70 & 10.92 & 10.31 \\
\hline Fenoxaprop-p-ethyl $+\mathrm{Si}_{250 \mathrm{ppm}}{ }^{\&}$ & 1.91 & 2.47 & 2.19 & 9.75 & 9.88 & 9.82 \\
\hline Fenoxaprop-p-ethyl +Si500ppm ${ }^{\&}$ & 2.33 & 2.49 & 2.41 & 9.05 & 10.58 & 9.82 \\
\hline Mean & 2.01 & 2.37 & & 9.86 & 10.93 & \\
\hline LSD $_{0.05}$ & 0.10 & & & 0.21 & & \\
\hline$F$ & 0.10 & & & 0.96 & & \\
\hline $\mathrm{N} \times \mathrm{F}$ & 0.26 & & & 0.57 & & \\
\hline
\end{tabular}

»: Sequence application of fenoxaprop-p-ethyl plus Si, \&: Tank mixing application of fenoxaprop-p-ethyl plus Si

value of flag leaf $\mathrm{N}$ and grain protein content were recorded with fenoxaprop-p-ethyl+Si500ppm and hand weeding, respectively.

Generally as a conclusion of the experiment I and experiment II, it is clear that Si has a substantial role for enhancing the growth and yield of wheat. Results of this study point out clearly that such effect occurred under $\mathrm{N}$ deficiency, where Si partially alleviated disadvantageous impact of low $\mathrm{N}$ supply. Despite Si has no direct effect on weeds elimination when applied with fenoxaprop-p-ethyl herbicide either in sequence or in tank mixture, it can overcome detrimental impact of this herbicide on wheat plants, besides enhancing the growth of Si-treated plants. Fortunately, such findings appeared under normal or stressed-N conditions. These effects undoubtedly will reflect on the competitive ability of the crop against weeds, thus more economic yield of the crop is expected. Moreover, the correlation between $\mathrm{Si}$ and biochemical components, i.e. proteins and others in whet plants needs more investigations.

\section{REFERENCES}

Agurie, S., W. Agata, F. Kubota and P.B. Kaufman 1992. Physiological role of silicon in photosynthesis and dry matter production in rice plants. J. Crop Sci. 61: 200-206.

Ahmad, S.T. and R. Haddad 2011. Study of silicon effects on antioxidant enzyme activities and osmotic adjustment of wheat under drought stress. Czech J. Genet. Plant Breed. 47(1): 17-27.

Ahmed, M., M. Asif and A. Goyal 2012. Silicon the non-essential beneficial plant nutrient to enhanced drought tolerance in wheat, Crop Plant, Dr Aakash Goyal (Ed.), INTECH, 31-48.

AOAC 1995. Official Methods of Analysis of the Association of Official Analytical Chemists. Washington, DC, USA.

Brar, L.S., U.S. Balia, and B.K. Dhaliwal 1999. Bioefficacy of new herbicides for the control of resistant Phalaris minor in wheat. Pest Res. J. 11(2): 177-180.

Cataneo, A.C., L.C. Ferreira, M.M. Mishan, E.D. Velini, N. Corniani and A.L. Cerdeira 2013. Mefenpyr-dieethyl action on fenoxaprop-pethyl detoxification in wheat varieties. Planta Daninha, Viçosa-MG. 31 (2): 387-393.

El-Metwally, I.M. and H.S. Saudy 2009. Herbicide tank-mixtures efficiency on weeds and wheat productivity. Ann. Agric. Sci., Moshtohor. 47(2): 95-109.

Epstein, E. 1994. The anomaly of silicon in plant biology. Proc. Nat. Acad. Sci. USA, 11-17.

Epstein, E. 1999. Silicon. Plant Physiol. 50: 641664.

Epstein, E. and A.J. Bloom 2003. Mineral Nutrition of Plants: Principles and Perspectives $\left(2^{\text {nd }}\right.$ Ed.), John Wiley \& Sons, New York, USA, 48-229.

Fallah, A. 2012. Study of silicon and nitrogen effects on some physiological characters of rice. Inter. J. Agric. Crop Sci. 4(5): 238-241. 
Gomez, K.A. and A.A. Gomez 1984. Statistical Procedures for Agriculture Research. A WileyInter Science Publication, John Wiley \& Sons, Inc. New York, USA. pp. 680.

Gong, H.J., K.M. Chen, G.C. Chen, S.M. Wang and C.L. Zhang 2003. Effect of silicon on growth of wheat under drought. J. Plant Nutr. 26 (5): 1055-1063.

Gong, H.J., K.M. Chen, G.C. Chen, S.M. Wang and C.L. Zhang 2005. Silicon alleviates oxidative damage of wheat plants in pots under drought. Plant Sci. 169: 313-321.

Hossain, M.T., M. Ryuji, K. Soga, K. Wakabayashi, S. Kamisaka, S. Fuji, R. Yamamoto and T. Hoson 2002. Growth promotion and increase in cell wall extensibility by silicon in rice and some Poaceae seedlings. J. Plant Res. 115: 23-27.

Jornsgard, B., K. Rasmussen, J. Hill and L.J. Christiansen 1996. Influence of nitrogen on competition between cereals and their natural weed populations. Weed Res. 36: 461-470.

Khan, I., G. Hassani, M.I. Khan and M. Gu 2007. Effect of wild oat (Avena fatua L.) population and nitrogen levels on some agronomic traits of spring wheat (Triticum aestivum L.). Turk. J. Agric. For. 31: 91-101.

Koscelny, J.A. and T.F. Peeper 1997. Herbicides for winter-hardy wild oat (Avena fatua) control in winter wheat (Triticum aestivum). Weed Technol. 11:35-38.

Liang, Y.C., S. Qirong and S. Zhenguo 1999. Effect of silicon on enzyme activity and sodium, potassium and calcium concentration in barley under salt stress. J. Plant Soil. 209(2): 217224.

Liang, Y.C., T.S. Ma, F.J. Li and Y.J. Feng 1994. Silicon availability and response of rice and wheat to silicon in calcareous soils. Soil Sci. Plant Anal. 25: 2285-2297.

Liang, Y., J. Si and V. Romheld 2005. Silicon uptake and transport is an active process in Cucumis sativus. New Phytologist. 167: 797804.

Liang, Y., Q.I.N. Chen, Q. Liu, W. Zhang and R. Diang 2003. Exogenous silicon (Si) increases antioxidant enzyme activity and reduces lipid peroxidation in roots of salt-stressed barley (Hordeum vulgare L.). J. Plant Physiol. 160: 1157-1164.

Ma, J.F., 2004. Role of silicon in enhancing the resistance of plants to biotic and abiotic stresses. Soil Sci. Plant Nutr. 50: 11-18.
Ma, J.F. and E. Takahashi 1990. Effect of silicon on the growth and phosphorus uptake of rice. Plant Soil. 126 (1): 115-119.

Ma, J.F. and E. Takahashi 2002. Soil, Fertilizer, and Plant Silicon Research in Japan, Elsevier, the Netherlands, $281 \mathrm{p}$.

Ma, J.F., K. Tamai, N. Yamaji, N. Mitani, S. Konishi, M. Katsuhara, M. Ishiguro, Y. Murata and $M$. Yano 2006. A silicon transporter in rice. Nature. 440: 688-691.

Mattas, K.K., R.S. Uppal and R.P. Singh 2011. Effect of varieties and nitrogen management on the growth, yield and nitrogen uptake of durum wheat. Res. J. Agric. Sci. 2 (2): 376-380.

Minolta 1989. Manual for chlorophyll meter SPAD 502. Minolta Co., Ltd., Radiometric Instruments Div., Osaka, Japan, p. 22.

Mitani, N. and J.F. Ma 2005. Uptake system of silicon in different plant species. J. Exp. Bot. 56: 1255-1261.

Morimiya, Y. 1996. Role of Si in production of low protein rice and diagnosis parameters. Ipn $\mathbf{J}$ Soil Sci Plant Nutr. 67: 696-700.

Mukkram, A., T. Rahmatullah, A. Tariq, M. Ashraf, K. Shamsa and M.A. Maqsood 2006. Beneficial effects of silicon in wheat (Triticum aestivum L.) under salinity stress. Pak. J. Bot. 38 (5): 1715-1722.

Ranganathan, S., V. Suvarchala, Y.D. Rajesh, M.S. Prasad, A.P. Padmakumari and S.R. Voleti (2006). Effect of silicon sources on its deposition, chlorophyll content, and disease and pest resistance in rice. Biol. Planta. 50: 713-716.

Rodrigues, F., D.J. McNally, L.E. Datnoff, J.B. Jones, C. Labbe, N. Benhamou, J.G. Menzies and R.R. Bélanger 2004. Silicon enhances the accumulation of diterpenoid phytoalexins in rice: A potential mechanism for blast resistance. Phytopathol. 94: 177-183.

Saudy, H.S., M.S. El-Habbal, F. Ashmawy, E.M. Soliman and K. Iman Abbas 2008. Using chlorophyll meter for predicting wheat nitrogen requirements. Ann. Agric. Sci., Moshtohor. 46 (4): 299-308.

Senseman, S.A. 2007. Herbicide handbook. $9^{\text {th }}$ Ed., Weed Science Society of America, Champaign, $458 \mathrm{p}$.

Singh, B., Y. Singh, J.K. Ladha, K.F. Bronson, V. Balasubramanian, J. Singh and S. Khind 2002. Chlorophyll meter and leaf color chartbased nitrogen management for rice and wheat in Northwestern India. Agron. J. 94: 821-829. 
Singh, R.K., D.K. Singh and R.P. Singh 1997. Weed crop competition in weed as affected by different weed species. Indian J. Weed Sci. 29: 199.

Sobh, M.M., M.S. Sharshar and A. Soad El-Said 2000. Response of wheat plants to nitrogen and potassium application in salt affected soil. J. Product. 5: 83-97.

Soltani, N.N., C. Shropshire and P.H. Sikkema 2011. Sensitivity of durum wheat (Triticum turgidum) to various postemergence herbicides. Agric. Sci. 2(4): 451-456.

Tahir, M., A. Rahmatullah, T. Aziz, M. Ashraf, S. Kanwal and M.A. Maqsood 2006. Beneficial effects of silicon in wheat (Triticum aestivum,
L.) under salinity stress. Pak. J.. Bot. 38(5): 1715-1722.

Valenti, S.A. and G.A. Wicks 1992. Influence of nitrogen rates and wheat (Triticum aestivum) cultivars on weed control. Weed Sci. 40: 115121.

Wilson, B.J., R. Cousens and K.J. Wright 1990. The response of spring barley and winter wheat to Avena fatua population density. Ann. App. Biol. 116: 601-609. 